


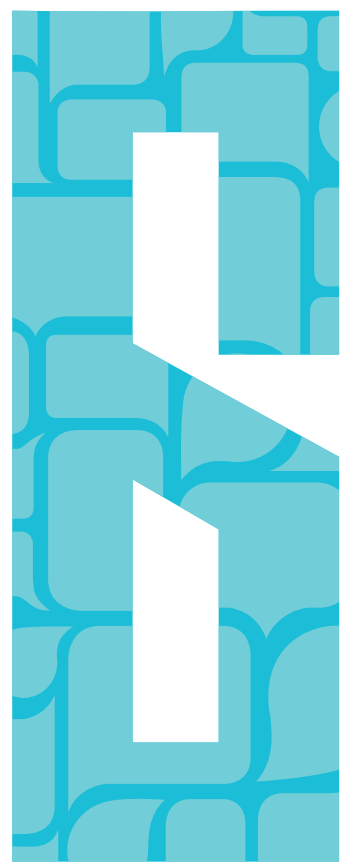




\section{Estudo de caso: morro da macumba}

O Morro da Macumba é uma região do bairro Parque Residencial Cocaia, Zona Sul de São Paulo e recebeu esse nome por ter sido no passado um local de despejo de muitos corpos mutilados, advindos da violência devastadora que atormentou essa área por anos. Neto ${ }^{25}$ explica que o termo Macumba foi associado ao bairro pelos pastores evangélicos, leigos em religiões, que deram esse nome por causa do aspecto ali encontrado, que era de medo e escuridão. Por meio do depoimento de Dalila Angioleto ${ }^{26}$ podemos ter uma visão de como era a região:

Teve uma época lá no Morro que era desmanche de carro. Veio um helicóptero e com tiros de cima para baixo matou uns três ou quatro. Inclusive conhecíamos um rapaz. O Morro da Macumba só tinha macumba o que tinha de despacho, talvez porque tinha muito mato.

Os primeiros moradores foram para esse bairro como uma única solução de fugir dos problemas da vida, como Jonato Rodrigues ${ }^{27}$ descreve: "Todos eles, fugiam: uns fugiam da polícia, outro dos bandidos, uns do aluguel, outros do nordeste. Enfim, todos fugiam."

As memórias individuais de cada um dos moradores representam como foi o nascimento do bairro; a maioria veio do Nordeste, assim como outros milhares de nordestinos que chegam a São Paulo em busca de uma vida melhor. ANGIOLETO ressalta que: "quando chegamos aqui não tinha nada. Uma casa aqui e outra ali. Não tinha água, não tinha luz." Outra moradora, Ilda Vieira ${ }^{28}$ complementa esses relatos do início do bairro:

Quando o recanto foi fundado isso aqui era só mato, não tinha muitos moradores, só uns três ou quatro neste lugar aqui e aos poucos foram vindo outros. Dos fundadores restam poucos a maioria foi embora. A nossa luta maior aqui foi água, luz, lixo. Deu muito trabalho. As pessoas tinham que pegar água numa biquinha lá longe. A água encanada não chegava até aqui então começamos a trazer água encanada por canos pretos e finos por baixo da terra e distribuímos entre nós um emprestado do outro.

25 Morador do bairro há 12 anos. Morava no Jardim Eliana antes de ir para o Parque Residencial Cocaia

26 Moradora do bairro desde 1972.

27 Artista plástico e graffiteiro, morador do bairro Parque Resicencial Cocaia, idealizador do projeto Morro da Macumba. Seus pais foram um dos primeiros moradores. 
Foram muitas as lutas diárias enfrentadas por esses moradores. Desde os problemas com saneamento básico e de estrutura: "não tinha chuveiro então enchíamos um balde com água e esquentávamos e jogávamos dentro de outro pendurado com furos embaixo." (ANGIOLETO). Outro grave problema enfrentado pelos moradores era a violência, hoje em proporções menores, mas que no início eram preocupantes. José Franscico Costa $^{29}$ relata que a violência era presente na marginalidade espalhada pela região e pelo medo imposto pelos traficantes:

Houve um tempo em que realmente as coisas eram feias, mas conosco não tivemos nenhum problema. Chegou uma época em que os traficantes queriam cobrar dos maradores para fazer segurança local. Há uns 7 ou 8 anos, mas me recusei e nada aconteceu conosco. Acredito em Deus. Acha que eu vou financiar a marginalidade? Por favor, me respeitem, quem guarda meu lar é Deus.

Ivan Cariri ${ }^{30}$ faz um desabafo onde a apresenta as outras vertentes da violência:

Os caras falam de violência, a violência pra mim é um pacote: o desemprego é uma violência, a falta de perspectiva é uma violência. A falta de áreas de lazer para os jovens é uma violência. A fome é a maior de todas as violências. E tem muita gente passando fome.

Os problemas enfrentados por essas pessoas é o reflexo de como é o processo de criação de áreas de moradias nas periferias do Brasil. Falta todo um amparato que é de direito de cada cidadão e que só é alcançado ao longo dos anos, em alguns casos, até hoje faltam sanemaneto básicos e ruas asfaltadas.

Se hoje o bairro Parque Residencial Cocaia se encontra em melhores condições, se deve à luta de seus moradores. Além de serem a peça-chave da formação da memória coletiva desse espaço, seus protestos e revoluções foram de grande importância. A educação no bairro era de péssima qualidade, não haviam professores para dar as aulas. A prefeitura, na época, dizia que não tinham alunos suficientes para abrir uma escola. VIEIRA relata o que fizeram para inverter essa situação:

Juntamo-nos em umas 20 pessoas e fizemos um varal com os cadastros das crianças penduradas em um varal. Pra você ter uma ideia, esticamos o varal na rua e ainda faltou rua para que o varal se esticasse por completo. Na reinvidicação muitas pessoas se comoveram

29 Morador do bairro há12 anos.
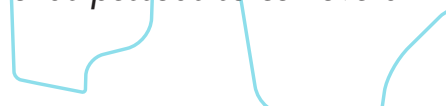

30 Geraldo lyan de Souza, pernambucano, mora no bairro há 20 anos. 
e nos ajudaram. Foi aqui que mandaram alguns professores mas aí a situação ainda era precária, pois faltavam carteiras e cadeiras pros alunos sentarem, então sentavam no chão.

Outro grande idealizador de propostas de melhoria para o bairro é CARIRI, que faz o seu relato perante a necessidade de se pensar em combater a violência com propostas de cidadania para os jovens:

Então começamos através das associações a tentar encaixá-los em projetos sociais. Consegui vagas para alguns no pró-jovem. Alguns me agradecem até hoje. Fui assim, trabalhando assim. Eu era presidente da associação Cariri. Sempre lutava por asfalto, saúde e melhorias para nossa região. Fiz muitos trabalhos voluntários como mutirão de saúde, odontologia, aquisição de documentos. Sou um cara sempre na ativa.

Todas as lutas, protestos e reinvindicações refletem no panorama que vemos nesse lugar e nos faz perceber como tudo foi feito às pressas e como isso influenciou a estrutura que hoje se vê: tijolos vermelhos, casas sem acabamentos ou pinturas, construídas uma em cima da outra, algumas ruas com asfaltos outras não. Agora eles tem escolas, farmácia, padaria, transporte público, postos de saúde, etc.

O Morro da Macumba é considerado até hoje um local que carrega em si a desgraça e o abandono. Não é a visão dos moradores que ali permaneceram, pois para eles apesar das histórias passadas, hoje trata-se de um local que cada dia acolhe mais e mais pessoas. O espaço onde eles habitam é formado pelas lembranças e relatos de cada um, que mantém viva as expectativas de uma vida cada dia melhor.

\subsection{0 projeto Morro da Macumba}

Viver em um local que é considerado amaldiçoado faz com que muitas pessoas não queiram nem pensar no seu passado. Mas um morador resolveu conhecer melhor a história do bairro onde cresceu, primeiramente através dos relatos de seus pais e vizinhos. E percebeu que o desejo de resgatar as raízes culturais do bairro se misturava com o resgate da sua própria identidade. É possível observar durante os relatos esse entrelaçamento:

"Aos poucos, já mais velho, eu fui entrando na ondinha do movimento urbano, andar de skate, fazer tag na rua. E foi quando rolou o meu primeiro contato com graffiti. Quando me deparei com aquilo na parede eu falei: "Isso é feito com o quê? Com spray? Impossível". Era um tipo de acesso à informação, do que era aquilo e como fazer aquilo em si, que não tinha. Surgiu toda uma identificação com essas coisas, com esses movimentos que vêm da rua."(RODRIGUES, Jonato.) 
Essa apresentação entre RODRIGUES e o graffiti permitiu a ele o uso de vários experimentos para concretizar as ideia para um projeto para o bairro, como o exercício de olhar a cidade, apreender seus movimentos, suas contradições e realizar os registros artísticos. Da elaboração das poesias sobre o Morro da Macumba, surgiv o desejo de ir além de simples textos e ampliar o trabalho em uma narrativa gráfica, como RODRIGUES (2009, s.l.) apresenta: "a ideia do projeto Morro da Macumba surgiu a partir da vontade de contar uma história; era uma vontade de fazer um graffiti diferenciado; era a vontade de juntar as potencialidades artísticas de cada um."

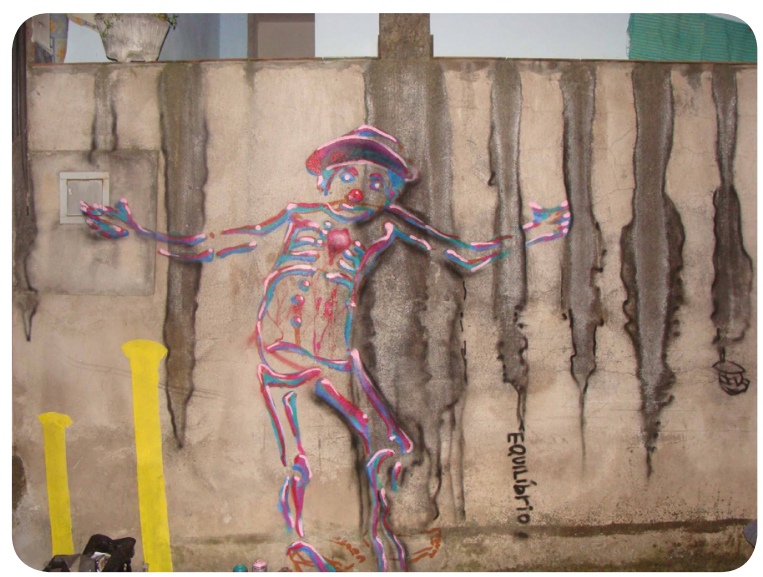

Figura 73. Estudos e referências - processo de criação Morro da Macumba Fonte: Arquivo Jonato

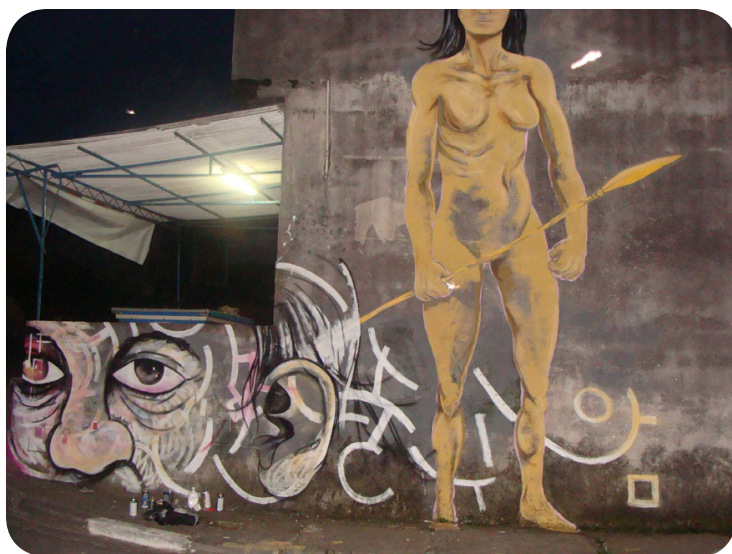

Figura 74. Estudos e referências - processo de criação Morro da Macumba Fonte: Arquivo Jonato.

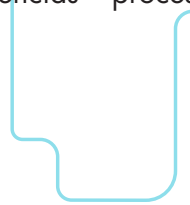


A partir disso, Jonato e sua esposa Paula Dias deram início ao planejamento do projeto do Morro da Macumba. Mas qual o tema ou dialética que eles poderiam utilizar? Resolveram utilizar a ideia de resgate da história do bairro como expoente gráfico.

O processo de elaboração desse projeto teve início com a gravação dos depoimentos dos moradores mais velhos do bairro e que tiveram importância para o crescimento do mesmo. Após as gravações, Jonato e Paula escreveram todos os depoimentos em folhas de sulfite (já que não possuíam computador) para poderem utilizar no entendimento da história. Após essa etapa, eles partiram para a escolha do suporte onde seriam aplicadas as artes. Então, decidiram realizar as pinturas na fachada das casas da Rua 9, a única sem asfalto e que lembrava as antigas vielas no início da formação da região.

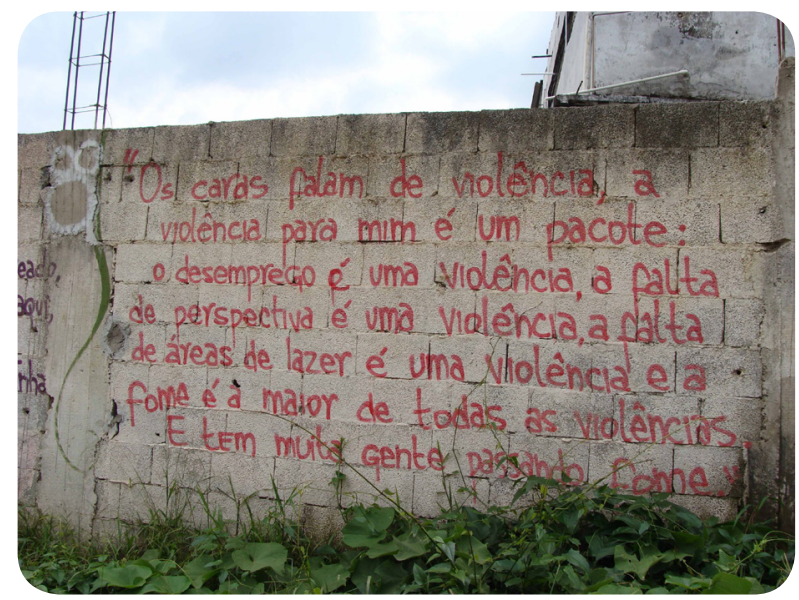

Figura 75. Trecho dos depoimentos dos moradores.

Fonte: Arquivo Jonato.

Foram selecionadas quinze casas.
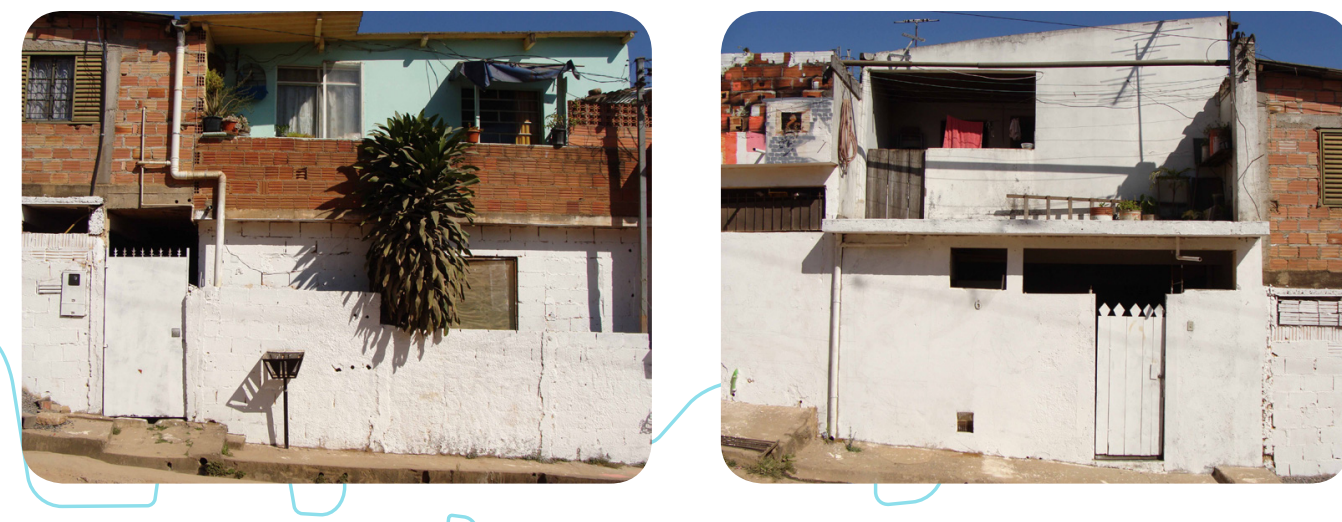

Figura 76. Fachada das casas antes das pinturas.

Fonte: Arquivo Jonato. 
No decorrer dos trabalhos de pesquisa, Jonato e Paula chamaram os irmãos Everaldo e Ronaldo, artistas plásticos da região para fazer parte do processo. A inserção dos irmãos proporcionou ganhos estéticos incríveis ao projeto, já que eles têm noções de histórias em quadrinhos, escultura e artesanato.

Com o briefing elaborado, eles realizaram a inscrição do projeto no VAI - Programa para a Valorização de Inicitiativas Culturais - da Prefeitura de São Paulo, que incentiva a propagação de projetos culturais. Esse programa seleciona, entre os inscritos, aqueles cujos trabalhos valorizem a cultura local e atue diretamente na comunidade, com cursos, workshops, palestras, etc. Não basta apenas ter um projeto artístico; é necessário que este seja um mediador de significados e valores na comunidade, além de proporcionar aos moradores o convívio com a cultura, já que esta muitas vezes fica limitada a eleita da sociedade.

O projeto Morro da Macumba foi selecionado pelo Programa e recebeu $\mathrm{R} \$ 19.000,00$ para ser colocado em prática. Os integrantes do projeto então foram às compras dos materiais necessários.

Os trabalhos foram iniciados e movimentou os moradores do bairro: uns curiosos, outros sem entender nada, outros preocupados em não admitir que pintasse suas casas, outros dispostos a ajudar. Além das pinturas, foram utilizadas esculturas de árvores.

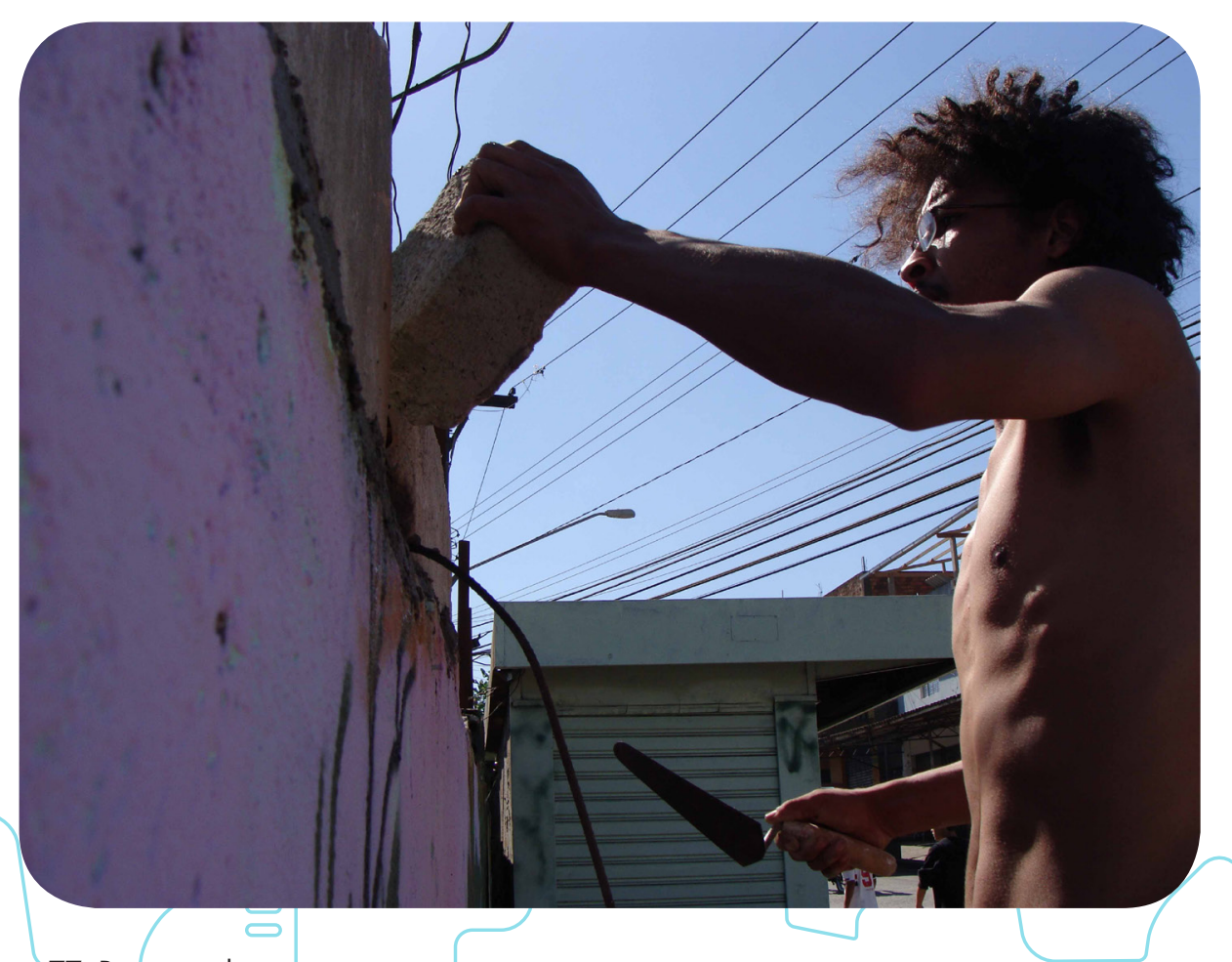

Figura 77. Processo de execução do projeto Morro da Macumba.

Fonte: Arquivo Jonato. 

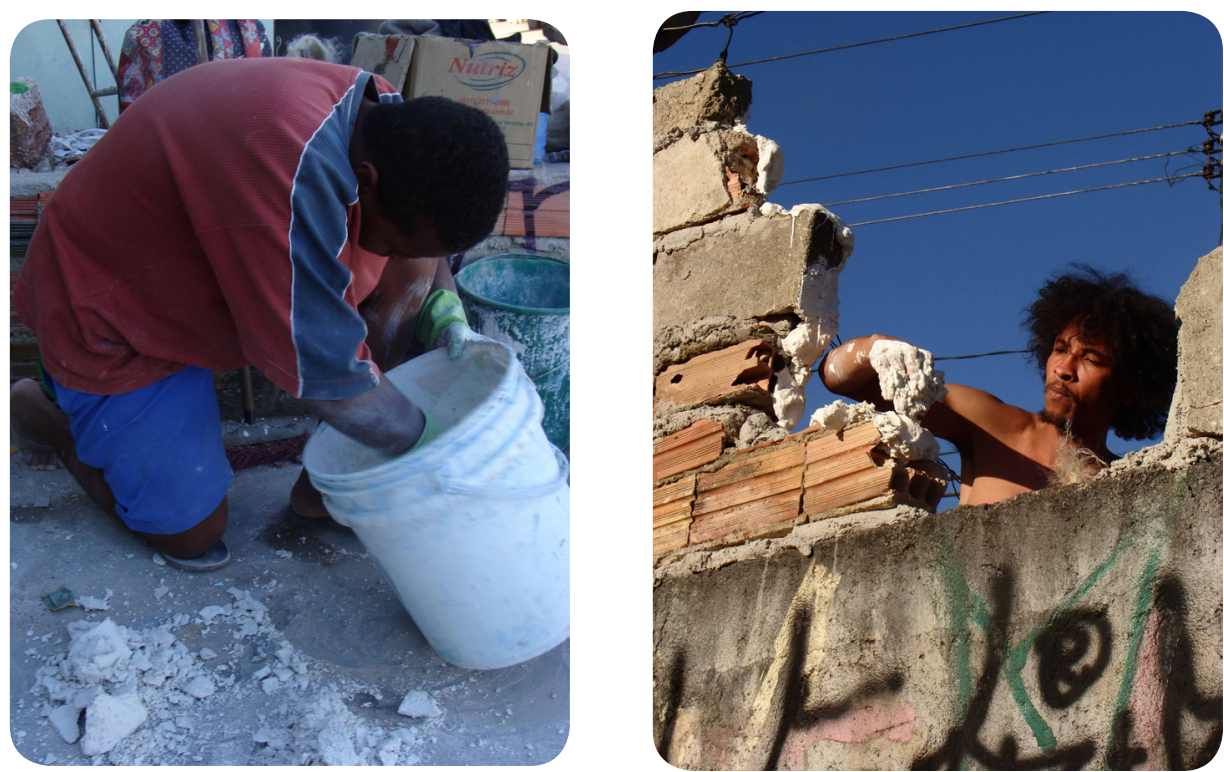

Figura 78. Processo de execução do projeto Morro da Macumba. Fonte: Arquivo Jonato.

Durante o processo de execução, os integrantes do projeto ensinaram aos moradores, em um workshop, a criar folhas de árvores de garrafa pet. Com essas folhas, foi possível a criação de árvores falsas que representassem o início do bairro, que era cercado por mato.

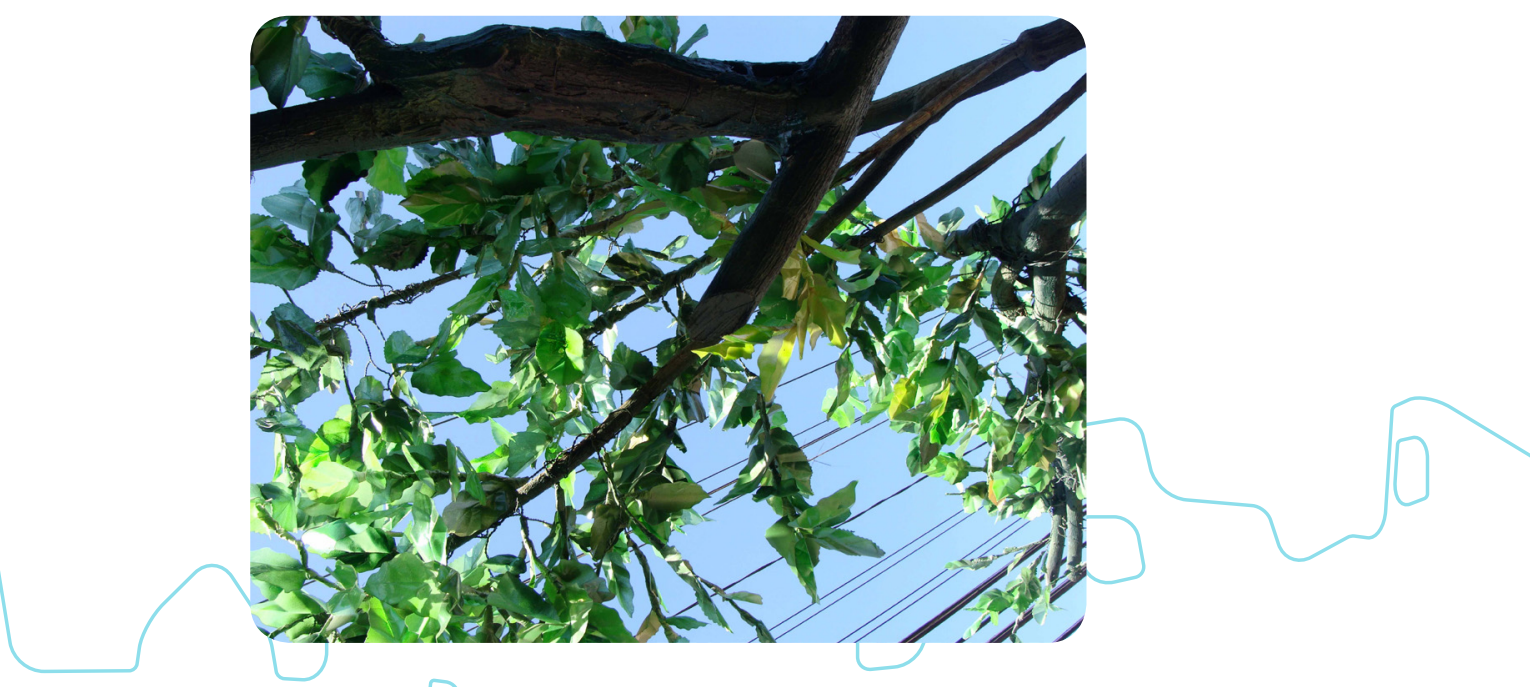

Figura 78. Folhas criadas com garrafa pet pelos moradores.

Fonte: Arquivo Jonato. 
Como não havia árvores reais para representar essa etapa da narrativa gráfica, os artistas montaram troncos falsos com material sintético para acoplar as folhas de garrafa pet.

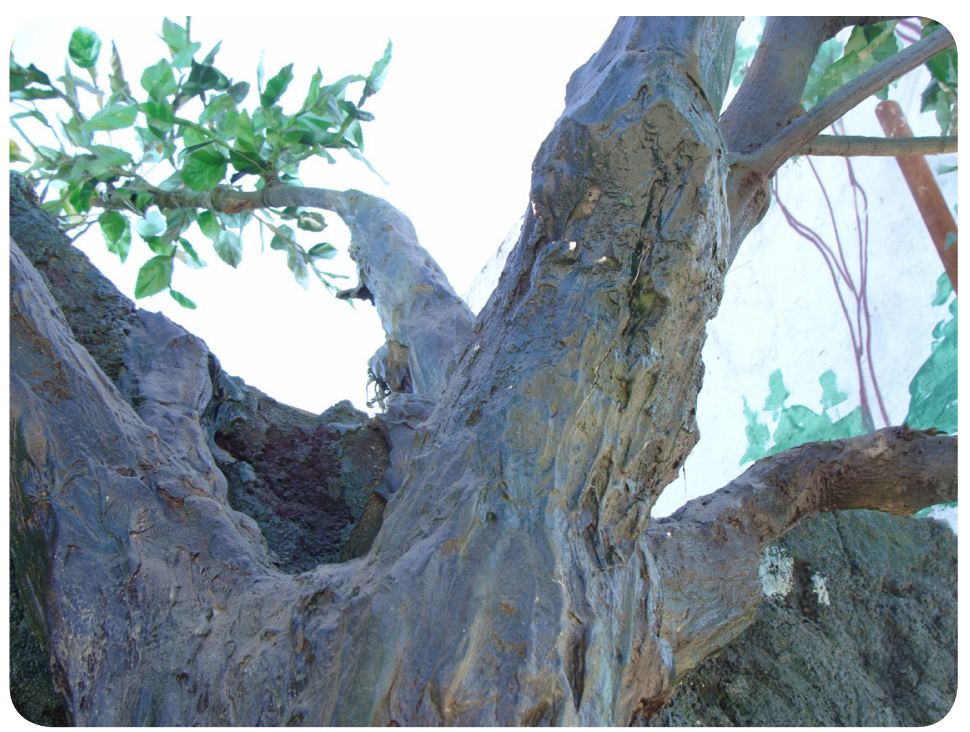

Figura 79. Tronco de árvore montado com material sintético.

Fonte: Arquivo Jonato.

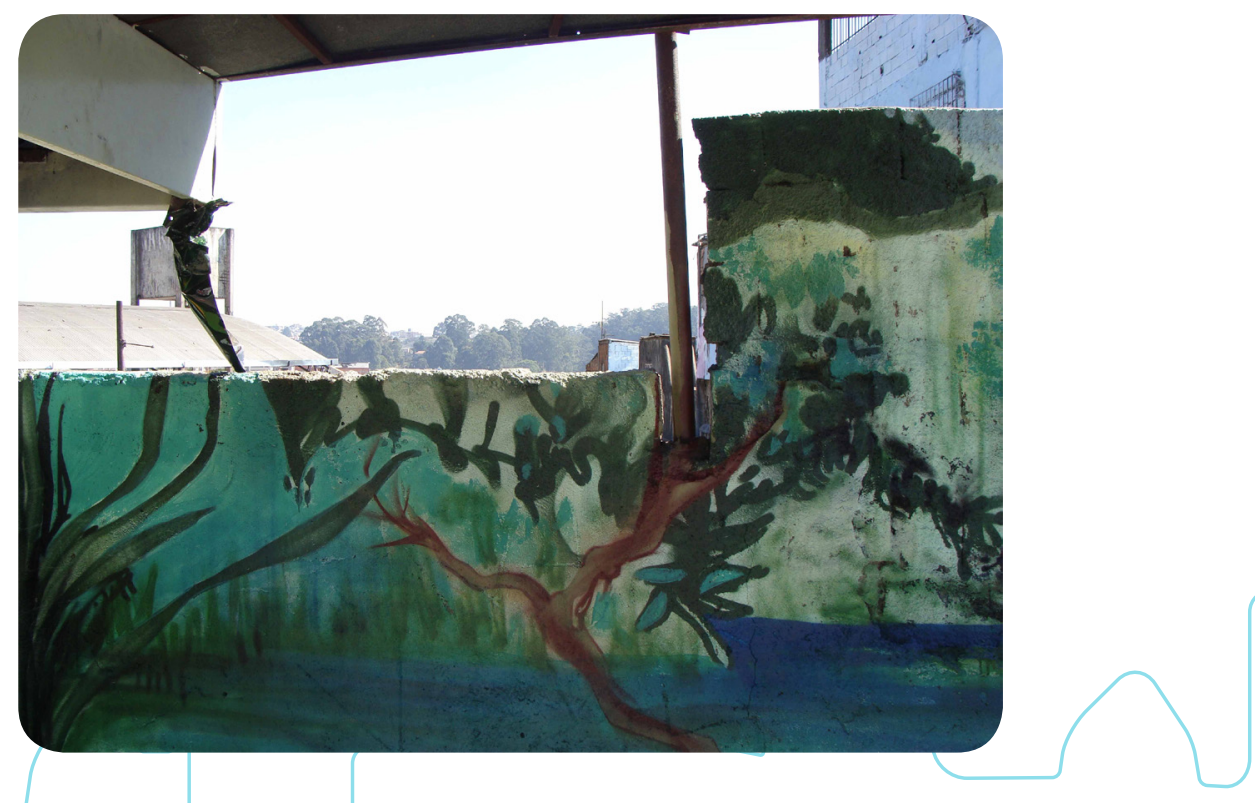

Figura 80. Parede escolhida para colocação de uma das árvores.

Fonte: Arquivo Jonato.

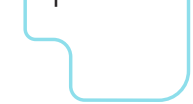


O resultado ficou impressionante. Quem passava pelo local não acreditava que as árvores não eram reais.
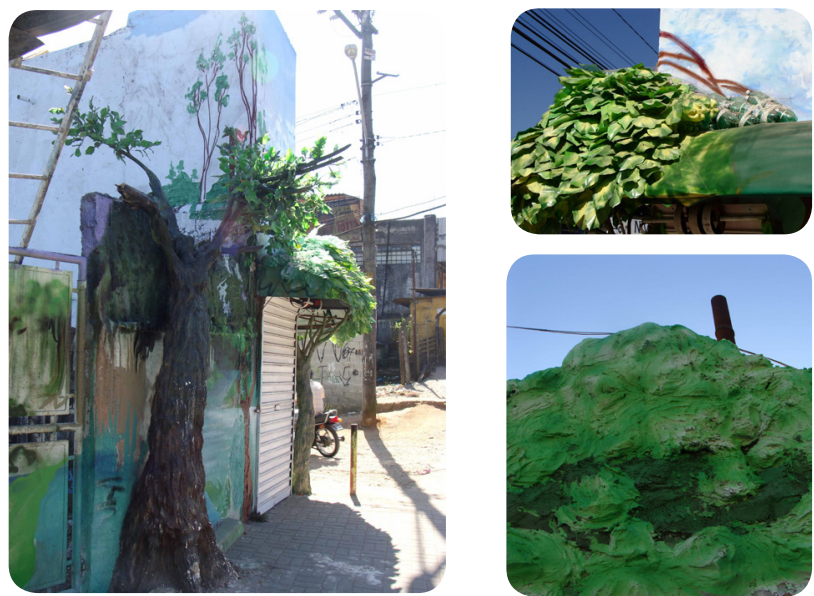

Figura 81. Árvores finalizadas.

Fonte: Arquivo Jonato.

Os desenhos criados acompanham os elementos presentes nas fachadas, enriquecendo o trabalho.

Os irmãos Everaldo e Ronaldo criaram elementos de perspectiva nos desenhos. Indo além, elaboraram outros itens apara expandir o campo de visão do trabalho e com isso permitiram que as pessoas tivessem a sensação de estar saltando do espaço.

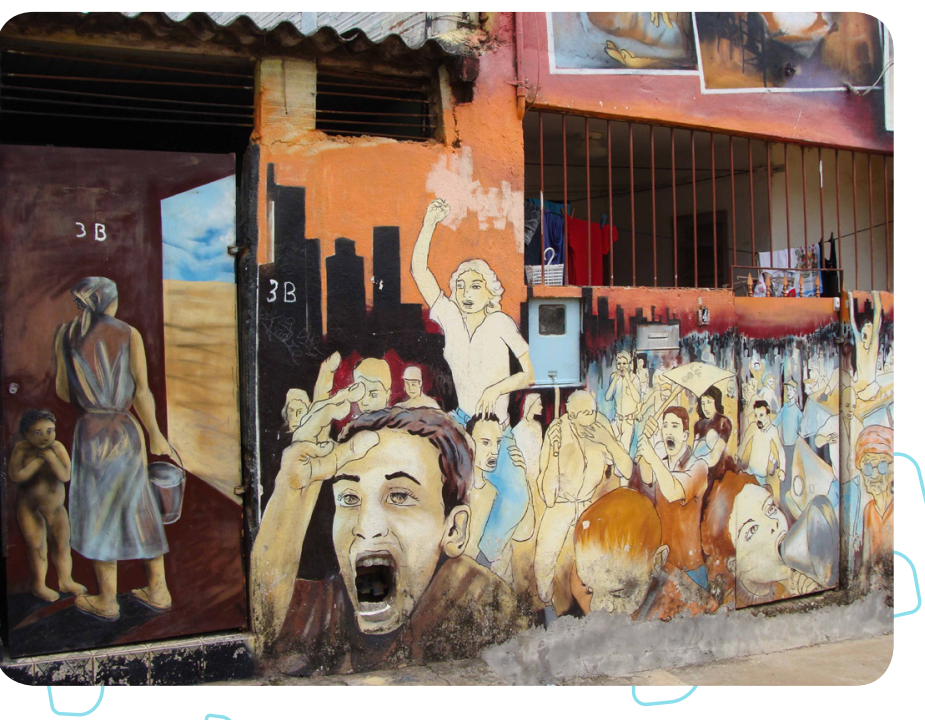

Figura 82. Perspectiva e uso dos elementos presentes nas fachadas compondo os desenhos.

Fonte: Arquivo Jonato. 

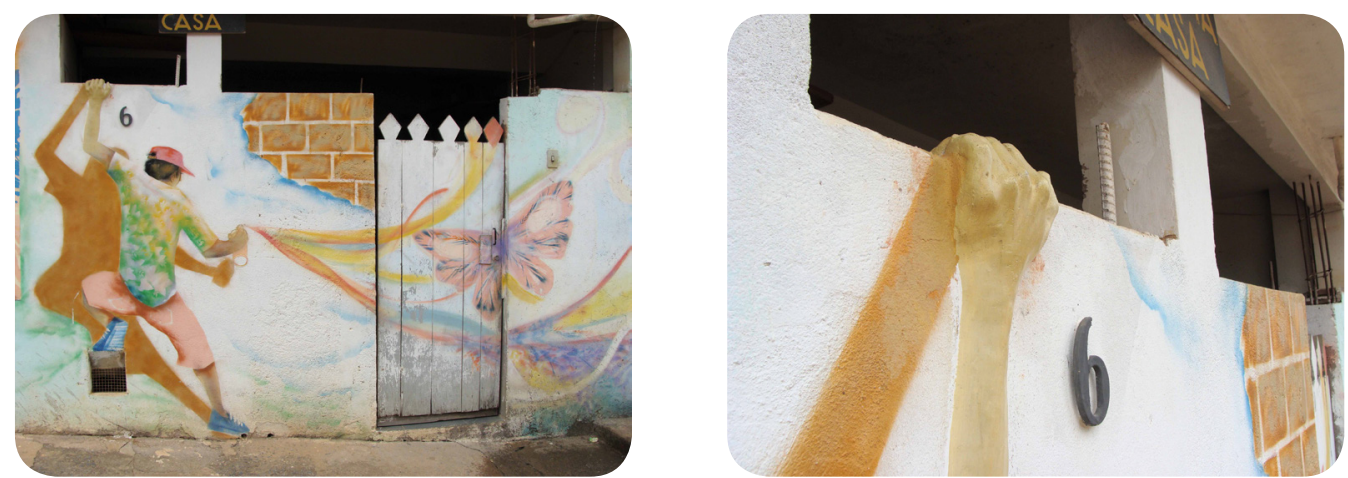

Figura 83. Mão feita com gesso, passando a sensação de estar saltando da parede. Fonte: Arquivo Jonato.
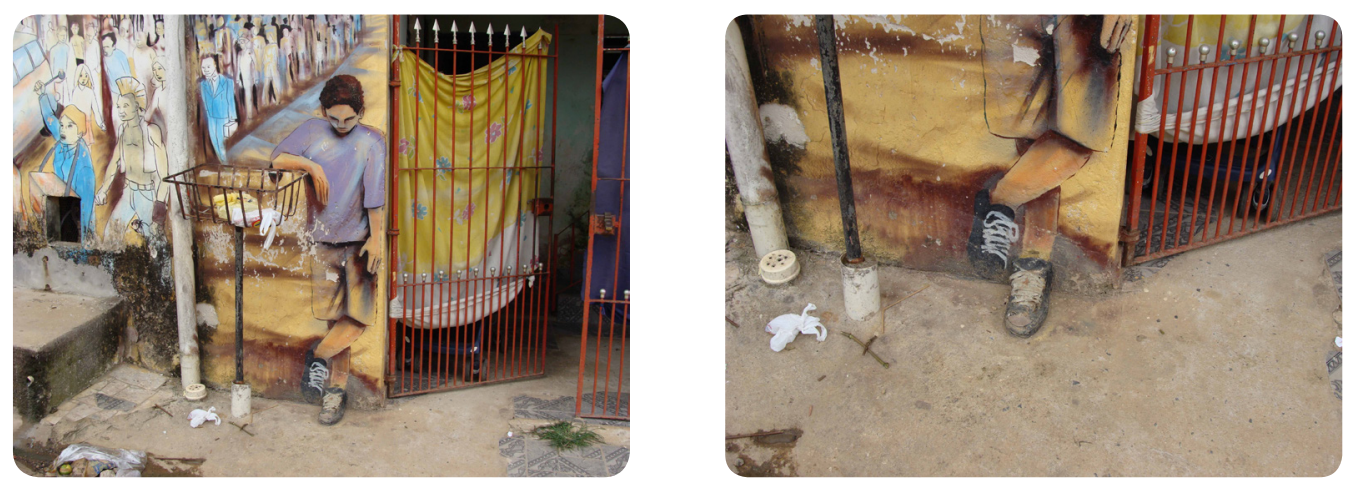

Figura 84. Sapato feito com gesso, passando a sensação de estar saltando da parede.

Fonte: Arquivo Jonato.

Após a finalização dos trabalhos, o talento e a criatividade estavam expressas nas fachadas da rua de terra do Parque Residencial Cocaia. Conforme os artistas comentaram, o projeto finalizado teve uma ótima repercussão na mídia. Foram vários convites para participar de outros projetos culturais.
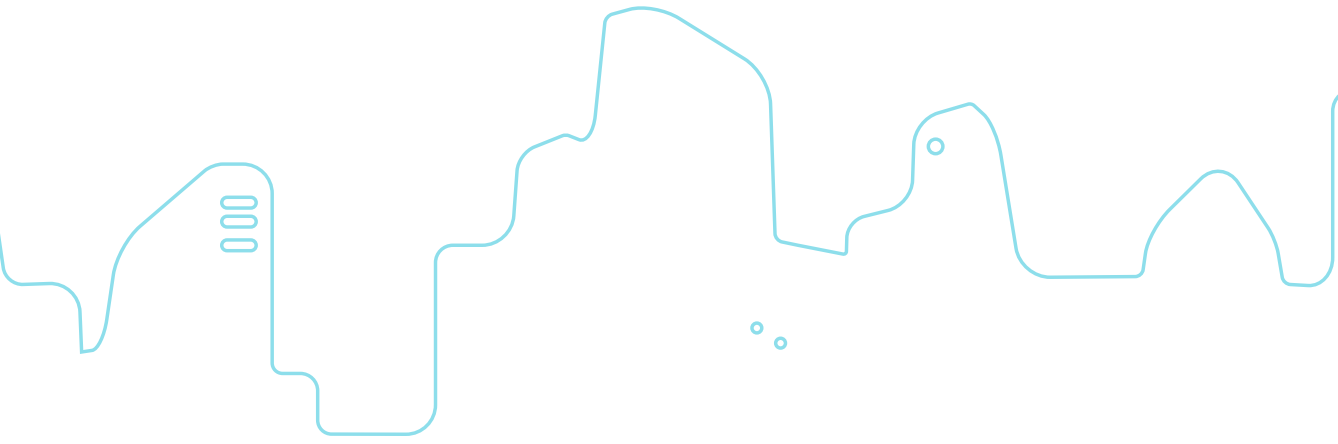

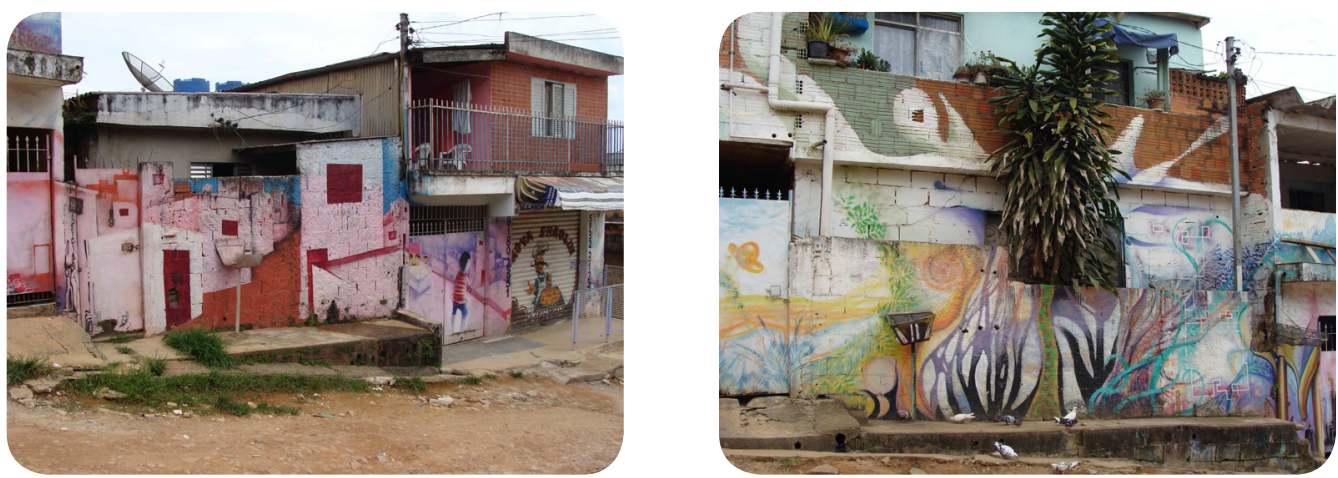

Figura 85. Projeto finalizado.

Fonte: Arquivo Jonato.

A proposta do trabalho nos apresenta uma nova visão sobre como pensar o espaço onde vivemos. Não foi apenas uma pintura para dar uma nova perspectiva para o bairro. O projeto Morro da Macumba foi pensado e elaborado de forma a ser um atuante cultural na comunidade no qual ele está inserido. A Arte, assim como o Design, também precisa ter a sua vertente de atuação social para expandir e difundir a cultura.

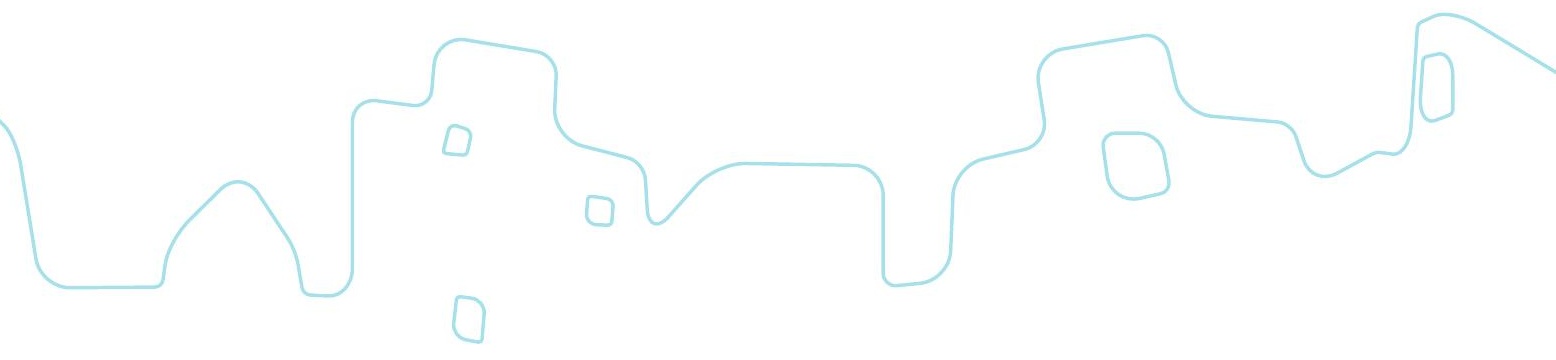


